\title{
The Ottawa Field-Naturalists' Club Awards for 2019, presented February 2020
}

\author{
Eleanor Zurbrigg, Irwin Brodo, Julia Cipriani, Christine Hanrahan, Lynn Ovenden, and \\ Karen McLachlan Hamilton
}

On 22 February 2020 members and friends of the Ottawa Field-Naturalists' Club (OFNC) gathered for the Club's Awards Night at St. Basil's Church in Ottawa to celebrate the presentation of awards for achievements in the previous year. Awards are given to members or non-members who have distinguished themselves by accomplishments in the field of natural history and conservation or by extraordinary activity

\section{Member of the Year: Martha Farkas}

Each year, the Ottawa Field-Naturalists' Club recognizes a Club member whose exceptional accomplishments during the past 12 months stand out from the crowd. For 2019, that would surely be Martha Farkas, in recognition of her leadership on the remarkable May birding trip to Point Pelee National Park and Rondeau Provincial Park.

Why was the 2019 trip remarkable? Every other year for many decades, the OFNC has been organizing and running trips to Point Pelee in Essex County, Ontario, to observe the spring bird migration over a long weekend in May. This past year was special because there had been a three-year rather than two-year hiatus and the number of participants rose to close to 40 , with the need for three birding leaders instead of two. In addition, the trip was to be a five-day event instead of the usual four days (including travel time). Finding an administrative leader who is not only willing to put in the large amount of time and effort required to make such a trip happen, but with the skills required to make the trip a success, is not always easy. The Club found just such a person for the 2019 trip, Martha Farkas, who had already learned some of the ropes by leading the previous Pelee trip.

Martha looked after all the administrative details for the excursion, starting two years before the event by reserving rooms for the entire group at a motel in within the Club. Four Club awards were presented for 2019, for: (1) outstanding organization of the Club's five-day bus excursion to Point Pelee National Park, (2) worthy service including as the Book Review Editor for The Canadian Field-Naturalist, (3) revitalizing the Conservation Committee and promoting conservation of regional forests, and (4) habitat preservation in the Ottawa Valley.

Leamington, close to the park. Martha also arranged for the bus and driver months in advance. All the payments and purchases were also dealt with by Martha, looking after last-minute changes, fees, non-payments, and inevitable questions. Taking care of the financial issues is something not all Pelee trip organizers have had to do. After the all-day bus trip, and after the participants were settled at the motel, she organized the shopping for picnic lunches and later devised a way for people to put the picnic lunches together and do the required clean-up. Needless to say, she had to constantly keep track of over 35 excited and preoccupied birders both in the field and back at the home base. Always attentive to important details, Martha also brought a generous number of snacking options and water for the bus rides and was very aware of the necessity of mini-breaks on a bus with one washroom!

As one participant noted, "Martha is the consummate diplomat dealing with people. She ensured that everything ran smoothly over the three days [in the field]. She was very good at managing the movement of the participants. She stayed calm, kept order with ease while managing the schedule".

It is therefore our pleasure to recognize Martha Farkas as our Member of the Year for 2019.

(Prepared by Irwin M. Brodo and Julia Cipriani) 


\section{George McGee Service Award: Barry Cottam}

This award is given in recognition of a member who has contributed significantly to the smooth running of the Club over several years.

Like many who gravitate to the Ottawa FieldNaturalists' Club, Barry's fascination with the natural world came at an early age. He quickly learned that the outdoors offers an inexpensive, endless source of learning and enjoyment. He was, and still is, never bored. He learned of the Club initially through the Fletcher Wildlife Garden (FWG), a place a friend suggested he should "check out". That was the beginning of his nine-year adventure.

Barry really loves books. So, when The Canadian Field-Naturalist (CFN) needed a new Book Review Editor, the position seemed a natural fit. His primary responsibility is to manage the Book Reviews and New Titles sections seen at the end of every issue. Approximately 150 books have passed through his hands since assuming the position in 2016. Most are forwarded to reviewers; however, for books that may seem a little obscure or do not seem to fit a particular niche, Barry has risen to the challenge and reviewed them himself. His reviews have included topics such as Passenger Pigeons, enlightened naturalists, human enlightenment through nature, and climate change.

Being a Book Review Editor is not for the faint of heart. It requires good communication and editing skills, and the ability to organize and coordinate every item through the review process in a timely fashion.
This process can take $20-48$ hours a month to accomplish, depending on the complexity of the situation. Barry has also introduced a new twist to each review by adding a thumbnail image of the cover page. It is his natural curiosity, self-motivation, and easygoing personality that make him the editor he is.

It should be said that Barry's activities in the Club have not been restricted to CFN. When affiliated with the FWG, he served on its committee for four years, and led a small group attempting to rid the garden of Dog-strangling Vine. He was also FWG's representative to the Central Experimental Farm Advisory Committee and Friends of the Farm for two of those years. He served on the Board of Directors not only as FWG chair, but later as the OFNC representative to Ontario Nature. He left the Board in October 2016 to join the Publications Committee as Book Review Editor for CFN and Proofreader for Trail \& Landscape (T\&L). Other activities include six years as co-organizer of the Members' Photography Night and he occasionally contributes to the blog notes and T\&L.

As Barry is seriously considering living full time in Prince Edward Island, his active service will be winding down. With this in mind, the Club would like to acknowledge his invaluable contributions in general and to CFN specifically. Thank you, Barry, for a job well done.

\section{(Prepared by Karen McLachlan Hamilton)}

\section{Conservation Award-Member: Owen J. Clarkin}

This award recognizes an outstanding contribution by a member in the cause of natural history conservation in the Ottawa Valley, with particular emphasis on activities within the Ottawa District.

Eight years ago, for lack of a chairperson, OFNC's Conservation Committee was relatively inactive. Contact was mainly through intermittent emails. In October 2012, Owen offered to chair regular meetings to rebuild the committee. Owen brought energy and inspiration along with agendas, minutes, and ideas to Committee meetings. New members joined. A conservation program of advocacy, public outreach, and eco-inventories evolved.

Under Owen's influence and aided by other members, the Conservation Committee identified various issues on which they made submissions on behalf of the OFNC. For example, they sent comments to Ontario's Environmental Registry on the proposed hunting of Snapping Turtles and Double-crested Cormorants, to the federal government on recovery plans for endangered turtles and American Eels, and to the City requesting sloping curbs for turtle hatch- lings at Mud Lake and less mowing of meadows to support pollinators.

This advocacy for conservation has been balanced by ambitious public outreach. As Owen wrote in his 2015 Annual Report about the Conservation Committee, "We are keen to share our collective expertise with local nature lovers". Since 2012, he has led about 125 nature walks for over 20 groups, from naturalist organizations to community groups to horticultural societies. With boundless good humour, he tells people how to distinguish woody plant species by their buds, leaf venation, even their profile in the canopy on the horizon, plus information on their unique ecology. Tree Fest Ottawa described him as "Tree Educator, Activist, Treebadour".

From the beginning, one of Owen's personal goals for the Committee has been to learn the current status of uncommon or declining native plants in eastern Ontario and western Quebec. The Committee discusses and plans actions regarding species of conservation concern (both threatened indigenous species and emerging potentially invasive exotics). 
They have collaborated with several organizations on bioblitzes and inventories. Most recently, Owen conducted a tree inventory of Petrie Island with the Friends of Petrie Island and the Ottawa Stewardship Council. Under Owen's leadership, the group discovered several populations of extant Red Spruce throughout Eastern Ontario and noted other species growing in Red Spruce stands. Owen has also documented the region's threatened Rock Elm.

Owen leads and keeps the Conservation Committee together. He has developed effective positions on conservation issues for the OFNC Board and collaborated with almost every conservation group in the region. He is distinguished by his generosity in sharing knowledge with others, using education as a tool to promote appreciation and conservation of nature.

It is for revitalizing the Conservation Committee and promoting appreciation and conservation of regional forests and natural areas that the OFNC is pleased to present Owen Clarkin with the 2019 Conservation Award for a Member.

(Prepared by Lynn Ovenden)

\section{Conservation Award-Non-Member: Mississippi Madawaska Land Trust}

This award is given in recognition of an outstanding contribution by a non-member in the cause of natural history conservation in the Ottawa Valley, with particular emphasis on activities within the Ottawa District.

This year, the award is given to the Mississippi Madawaska Land Trust (MMLT) in recognition of their exceptional work protecting valuable wildlife habitat.

The MMLT was founded in 2003, and soon joined the Ontario Land Trust Alliance, adopting their Canadian Land Trust Standards and Practices. Without doubt, one of the best and most enduring ways to protect our native flora and fauna is to preserve habitats in perpetuity. The MMLT focusses on acquiring and protecting land in the Ottawa Valley just west of Ottawa, within the Mississippi River and lower Madawaska River watersheds. Their Mission Statement sums up their goals nicely: "To legally protect and steward private lands having ecological, biodiverse, aesthetic, and cultural value and to foster engagement with wilderness".

The land trust approach fits in well with this objective. Land trusts "are charitable organizations which are legally empowered to protect lands worthy of long-term conservation". The MMLT protects land in several ways: by accepting donations of land, by entering into conservation easements with landowners, and by outright purchase of land. At present, the MMLT stewards eight properties encompassing a diversity of habitats from forest to wetlands, meadows, and mountains. Four of these properties are open to the public for nature viewing, hiking, and snowshoeing.

Maintaining a land trust such as the MMLT requires considerable time and effort. While there is one paid part-time staff person, everything else is conducted by dedicated volunteers (a comprehensive Volunteer Handbook delineates the many important ways in which volunteers can assist). Acquiring

a property is the essential first step, followed by the preparation of maps and extensive documentation of the acquisition to satisfy legal requirements. Complete ecological assessments are also undertaken for each property including surveys of fauna and flora. As part of this process, the MMLT added an innovative acoustic monitoring of some sites during 2018. Plans are then prepared for ongoing monitoring and stewardship.

There are many costs associated with running such an organization. Financing is needed for legal fees, land appraisal, insurance, property taxes, and annual audits, and of course where applicable, buying land. Donations and membership fees contribute a significant amount. MMLT also applies for grants from various agencies for special projects, such as tree planting, the above acoustic monitoring, as well as to assist with the costs of land purchase. The MMLT holds their annual Go Wild Gala each autumn, with a silent auction which helps generate considerable funding. A wonderful array of guided walks and other events are held for which a modest fee is charged. There are hikes to see the fall colours on one of their most stunning properties, Blueberry Mountain, and excursions to other properties to discover lichens, watch birds, learn about wildflowers, search for dragonflies, and there is the delightfully named Festival of the Wild Child.

The MMLT is a dynamic, energetic, engaged group, completely dedicated to their vision of "wilderness protected for all time, where all species thrive and people engage with nature". They have been wonderfully successful in their relatively short time as a land trust and it is clear that they will continue to promote the joys and the beauty of nature as they protect yet more wild lands in the years ahead. For all of these reasons and for so much more, we are honoured to present the MMLT with the OFNC's 2019 Conservation Award-Non-Member.

(Prepared by Christine Hanrahan) 